César Augusto Cáceres Dagnino

Universidad de Piura (Peru)

Enrico Pinna

Università degli Studi di Cagliari (Italy)

\title{
The Generational Change in Family Businesses: \\ Comparative Analysis between Italy and Peru
}

\begin{abstract}
The aim of this paper is to understand how family firms in Italy and Peru prepare for generational change, by comparing three companies from each of these countries. After a theoretical analysis, having examined and compared the literature to define the family business, the business family and the generational change, an empirical analysis has been made using a quantitative survey (STEP 2013-2014) and its model, which makes a revision of a set of constructs, to identify if there is transgenerational potential in the business families. From the comparison of the six companies it appears that, contrary to what was initially thought, there are no such relevant differences. They are only diverse approaches to different problems of the same phenomenon. It is concluded that the six companies have an adequate transgenerational potential and are ready for a successful generational change.
\end{abstract}

Keywords: Family Businesses; STEP; Generational Change; Succession; Family; Company; Familiness; Undertaking

Corresponding author: e-mail: cesar.caceres@udep.pe

Received 11 May 2017 - Accepted 03 July 2017

This is an Open Access article distributed under the terms of the Creative Commons Attribution-Non-Commercial-No Derivatives License (http://creativecommons.org/licenses/by-nc-nd/4.0/), which permits non-comercial re-use and distribution, provided the original work is properly cited, and is not altered or transformed in any way. 


\section{Introduction}

Over the years, a growing number of international studies on family businesses have been conducted. In a review, Wortman (1995) found 144 family business studies focused on different countries; 84 (58\%) focused on the United States, Canada or the United Kingdom, and all were single country studies. From this, Wortman concluded:

«At present, there are practically no comparative studies about family businesses across cultural boundaries, ethnic borders and national boundaries. Are there really differences in the ways in which family businesses operate at sub-national, national or global levels? In what environmental or organizational contexts do family businesses operate more successfully?».

Since then, more studies have emerged focusing on family businesses in several nations and with greater consideration of contextual factors. Centeno-Caffarena (2006) found 120 articles published between 1977 and 2006 that examined the role of the institutional context of nations in family enterprises. A third of the studies involved the United States, but also other nations: Spain (15\%), China (6\%) and United Kingdom (6\%). The institutional factors most frequently examined were culture (17\%), values (15\%), gender (14\%), conflict (10\%), networks $(8 \%)$ and social capital $(6 \%)$.

In light of emerging evidence, Smith (2008) issued a call for «new empirical studies that control the context», noting that «the differences between family and non-family businesses may be less than many previous studies have indicated and that differences in industry and differences between countries may be more important».

Family businesses represent a generalized form of organization in the world economy (Beckhard and Dyer 1983; Ciambotti 1991; Shanker and Astrachan 2004) and they help define the level of employment, application models and educational schemes in many countries (Ward 
1987; Heck and Stafford 2001). Many of these companies are affected by the aspirations and values of the family (Chua and Chrisman 2003).

One of the most important and at the same time critical moments for a family business is the change of generation. It is a problematic and complex phenomenon that requires being able to be approached with the planning and the knowledge of the ideal strategic alternatives. Succession can be a key opportunity to spread the innovative spirit in the company and to initiate the process of change, which was carried out in accordance with a future-oriented logic, combining continuity and renewal, tradition and innovation.

The aim of this paper is to find out if there is any similarity between the six companies (three Italians and three Peruvian companies) by using a research carried out by STEP PROJECT, starting from the premise that generational change is the most difficult step for a family business. Given the number of companies studied, this work is not and does not want to be a statistical reference of what happens in Italian and Peruvian family companies, but only a starting point to reflect on the arguments that support this research.

STEP is a global research project led by Babson College that began in 2005. It is aimed at studying business families specifically in their transgenerational venture, which is the ability to grow and generate social and economic value and perpetuate this entrepreneurial legacy for many generations. It aims to understand the transgenerational nature of business groups and families by determining how they foster the creation of new entrepreneurial initiatives over the time.

\section{Family businesses and business families}

In the nineteenth century, and indeed in the twentieth century, economic activity was so 
dominated by family businesses (Harris 2000) that it was not necessary to give it a specific name to distinguish it from other legal and organizational forms. Only from the interwar period (Berle and Medios 1932), with a growing interest in property and control separation, historians and business management specialists have differentiated family businesses from other business categories. All definitions have been developed to analyze the specific transition, intergenerational, financial commitment, strategic control, and so on. However, it is absolutely clear that property is only part of the history (Gallo 1995).

When we talk about family businesses we do not refer to a homogeneous group of companies. Although similar traits can be identified, family businesses have a number of differences that involve some characteristic elements such as size, structure, management and governance. The heterogeneity that characterizes them makes difficult any form of classification. Many authors have defined the family business (Handler 1989; Chua and Chrisman 1999).

Recently, researchers have shown that it is misleading to see "family business" as a generic phrase, easily translated across economic and cultural boundaries. In fact, the definition of family business may vary internationally, and the form of family ownership may display different capacities in specific societies. Therefore, it is important to avoid a rigid definition of family businesses that masks the impact of family members on strategic decisions (Colli, Fernández, and Rose 2003).

Among the various definitions, the conceptual model proposed by Tagiuri and Davis (1992) is of a particular importance. The two authors have developed a simple linear model, according to which the business of a family can be represented by the intersection of two systems: family and business. Each system has its own rules, its own values and its own organizational structure. The problems of the family arise because the same individuals have obligations in both systems 
and because at the same time the company must dedicate itself to its own activities, and meet the needs of the family. Tagiuri and Davis (1992) have also explained that in many family businesses there is a distinction between ownership and management. Some family members own, but do not participate in management; others are not owners, but run the business. Consequently, the distinction between ownership and management could be as important as that between family and company. This distinction leads to the definition of a new model that describes family business as the result of three distinct but overlapping systems: business, property and family.

Often, the founder integrates the company into his life, as a personal thing, which is based on his creative abilities and sacrifices. It is from this context that often takes a contradictory attitude of the owner who, on the one hand, is aware of the need to adapt to the evolutionary cycles of his business and his life and, on the other, is reluctant to leave the command to the new generations.

In most cases, the first generation of family entrepreneurs had built their businesses through intuition rather than programming business development, supported by a risk appetite. The founder's experience in his business is not found in those who have followed. Having lived this experience in the company as the first (as the father of the first-born), it is believed that the governance of the firm can only take place in itself, centralizing all decisions (paternalistic system). Consequently, the transfer is difficult to manage because there is no alternative that has the same "historical value" or that is capable of assuming the responsibilities that have been, until now, only for the founder. In addition, the entrepreneur facing the first generational change faces obstacles that refer more to his executive capacity (will) than his strategic capacity (intelligence) (The generational continuity of the SME). 
In the literature, other important distinctions are presented between family businesses and business families. It is a different perspective than usual to study and examine family businesses. However, despite the many differences, they share the fact of having to manage the generational change.

The business family, unlike the family business, seeks that the descendants not only inherit ownership and, in many cases, the possibility of working in the company, but also acquire the necessary capacities so that they can replicate what the founders did. That is, they acquire the skills to start new businesses and integrate them into the family patrimony, if they wish. In this case, the rules that regulate the family-business relationship contemplate a series of additional aspects that contribute to the business group being maintained over time. The aim of all the business families is to achieve the continuity of the "entrepreneurial enterprise" in the future and for that reason they put the necessary means to foster the business growth.

In the early years of the family business, it is logical to confuse business and family values, as a member of the family is also the founder and manager of the business. However, as both the size of the company and the composition of the family increase due to the generational increase, it becomes necessary to differentiate both figures. Relationships among family shareholders become more complex as companies evolve and the leadership that in the first generation relapses without any doubt into the founder is diluted. This evolution in the life of the family business has led to the identification of three stages (Ward 1991).

The first stage (founder/controlling entrepreneur) is characterized by the confusion that occurs between management and ownership. The main concerns of the shareholders are the protection of the spouse in case of the founder death, inheritance and everything related to succession and leadership. At this stage, the overlap between family and business interests often occurs. The 
formal family organization is often not very necessary because since communication occurs automatically.

In the second stage (siblings' society) the division of actions takes the form of this type of society, where the main concern is to keep teamwork and family harmony. They begin to differentiate the family interests of the business interests. It is at this stage when processes must be established to formalize future management systems and governments.

In the third stage (cousins' consortium or family dynasty) the distribution of the property is complex, which causes the appearance of different types of shareholders belonging to the family, creating an atmosphere full of stress. It is at this stage when it becomes absolutely necessary to establish adequate instruments to avoid the end of the family business.

Table 1. Evolution in the life of the family business

\begin{tabular}{|c|c|}
\hline OWNERSHIP STAGE & SHAREHOLDERS' KEY PROBLEMS \\
\hline $\begin{array}{l}\text { STAGE ONE: } \\
\qquad \text { founder/founders }\end{array}$ & $\begin{array}{l}\text { Leadership transition. Succession. } \\
\text { Spouse protection. } \\
\text { Inheritance planning. }\end{array}$ \\
\hline $\begin{array}{l}\text { STAGE TWO: } \\
\text { sibling society }\end{array}$ & $\begin{array}{l}\text { Keep teamwork and harmony. } \\
\text { Support family ownership. } \\
\text { Succession }\end{array}$ \\
\hline $\begin{array}{l}\text { STAGE THREE: } \\
\qquad \text { cousins' consortium }\end{array}$ & $\begin{array}{l}\text { Tradition and family culture. } \\
\text { Resolution of family conflicts. } \\
\text { Participation and roles of the family. } \\
\text { Relation with the business. }\end{array}$ \\
\hline
\end{tabular}

The important changes that take place in markets and the different factors of competitiveness require new responses from families and companies. Generational change can be an opportunity to modernize management. The transition does not have to be traumatic and, in fact, if properly 
prepared, it can be experienced as a time when the family and the company develop, with renewed strength and continuity, the results of a lifetime's work.

\section{Italian and Peruvian family businesses}

Family businesses represent a key component of the region's economy on all continents, not only in terms of numerical incidence but, above all, for its contribution to the GDP and employment (see Table 2).

Table 2. Contribution to the GDP and employment

\begin{tabular}{|llll|}
\hline Continent & $\begin{array}{l}\text { \% family businesses of total } \\
\text { enterprises }\end{array}$ & \% GDP & \% employment \\
\hline Europe & 85 & 70 & 60 \\
\hline North America & 90 & 57 USA & 57 \\
& & 60 Canada & 70 \\
\hline Latin America & 85 & 60 & 70 \\
\hline Middle East & 90 & 80 & NA \\
\hline Asia-Pacific & 85 & 57 South of Asia & \\
& & 32 North of Asia & \\
\end{tabular}

Source: EY - Family Business Yearbook, 2014.

\section{Italian businesses}

It is estimated that in Italy family businesses are approximately 784,000 , corresponding to more than $85 \%$ of all the companies, and about $70 \%$ have an influence on the employment. An important difference compared to the main European economies is represented by the reduction in the use of managers outside the family: $66 \%$ of Italian family-owned companies have all 
management integrated by family members, whereas in France this situation is found in $26 \%$ of companies and in the UK only $10 \%$.

In Italy, family ownership and control remain important in both large and small companies. It is also interesting that the recent privatization process of the state conglomerates has considerably expanded the section of Italian industrial capitalism "controlled" by family businesses. Some very dynamic, family-owned companies such as Benetton, Del Vecchio (Luxottica glasses), Riva and Lucchini (special steels) bought large sections of the former statecontrolled conglomerates in the industry and distribution of iron and steel. On the other hand, the development of hierarchies within the dispersed productive structure of the industrial districts, of which some larger organizations are emerging, does not in any way question the traditional structure of the family (Colli, Fernández, and Rose 2003).

In the study carried out by PwC in 2014 , the conclusion was that only $9 \%$ of Italian family companies have a solid and documented succession plan; $58 \%$ of companies have not yet tackled the issue. And one family out of four does not have a procedure for conflict management; $46 \%$ of Italian family companies plan to transfer management to the next generation. The important data are that less than a third of companies survive the first generational change and less than one-fifth surpasses the second generation.

\section{Peruvian businesses}

In Peru, there are about 660,000 family businesses that correspond to almost $90 \%$ of companies throughout the country. Due to their great expansion, these generate $75 \%$ of the national GDP. The study carried out by PwC (2014) also indicates that 50\% of medium-sized family businesses are professionalized or intend to be, while $30 \%$ have a family protocol and only $10 \%$ have a strategic plan. 59\% of Peruvian family businesses are not willing to sell their businesses 
to third parties, a percentage higher than the $41 \%$ obtained from the global survey. Eighty-six percent of family businesses in Peru have at least one procedure and/or mechanism to deal with conflicts (which is slightly higher compared to the world average: 83\%). Focusing on the generational change, according to the study elaborated by the Inter-American Development Bank - IDB and the Chamber of Commerce of Lima - CCL, the important data are that only $30 \%$ of the family companies follow along with the second generation and only the $5 \%$ to the third (Jaramillo 2014).

\section{Succession}

Succession of companies should be considered as a process that requires careful planning (Barach and Gantisky 1995; Ip and Jacobs 2006), whose purpose is to ensure continuity. Numerous international studies (Beckhard and Dyer 1983; Kets de Vries 1993; Le BretonMiller, Miller, and Steier 2004; Ward 1987) found that there is a high risk of company closure during the succession phase to the second generation and even more so to the third generation of the family.

However, not all business succession processes determine the continuity of the organization within the same family of origin. In fact, in order to ensure survival, the entrepreneur might find himself in need (for lack of financial resources and/or lack of a valid successor) or opportunity (in the case of cost-effective sales price and/or low prospects of profits) to sell the company to third parties (Lassini 2005). In this situation, the continuity of the business is guaranteed by the sale of the company, but it results in the loss of the relationship with the family.

The success of generational change centers on the ability of the family to continue its existence 
over time because one or more descendants of the same family can take control of it (Corbetta1995).

In medium-large family businesses, succession may also involve the entry of external managers to entrust all or part of corporate governance (Compagno 1999). In small family businesses, for economic and affective reasons, generational change is generally carried out by transferring ownership and control of the enterprise to a child or children, identified as successors, whose capacity depends on the company's profit outlook and its own survival.

Although when we speak about succession, the real limits of the company do not appear in a defined way, in a theoretical process of succession three main phases can be clearly identified (McGivern 1978). The endurance and essential importance of these phases depends on the specific characteristics of the family business, on the sector of reference, the competitive environment, the organizational structure, the stage of development of the company and, above all, the personality of the entrepreneur and the influence of the whole family (Del Bene 2005). A first phase, prior to succession, can be identified at the moment when the entrepreneur realizes that he must delegate his own position. This awareness can arise from the foundation of the company, something that denotes a positive attitude with which the entrepreneur aims to promote business continuity over time, or in a negative sense, that the entrepreneur notices he is no longer heard or simply pretend to perpetuate his position in time.

The second phase of the process begins when the company identifies the potential successor figure within the family. This identification can be a source of family conflicts, as well as a source of problems of acceptance by the corporate structure. It should be noted that this phase is not always clearly separated from the previous one, in which the entrepreneur can develop a preference for the person to whom he intends to entrust the entrepreneurial role; but he may 
prefer not to show his preference to avoid conflictive situations and to achieve a gradual and natural acceptance of the successor by the other members of the family and the whole organizational structure. In the latter case, it is possible that this second stage begins without the formalization of a successor, but with the tacit identification of a person as a potential successor.

The third phase, later identified as the succession, is characterized by taking the real power of the successor (or successors). In this phase, coexistence between the old and the new generation can also be determined for a certain period of time. For succession to be considered as such, it is necessary that there had been a change of role between the two generations. It follows that the ancestor who continues to operate within the corporate structure simply has to play a supportive role, without affecting the decision-making or the autonomy management of the successor who took over the business function. However, if the successor does not have adequate business skills and talents at this stage, the beginning of the decline of the family enterprise can be identified, with the consequent reduction of future income prospects. On the contrary, succession can also be a development opportunity for the family business, realizing product innovations, processes or organizational changes required by the competitive environment, which is essential to keep the use of new skills in position of the successor or increase the competitiveness of the company over time.

According to some authors and numerous empirical studies (Boldizzoni, Cifalinò, and Serio 2000; Dyck et al. 2002; ARMAL 2003; Cucculelli 2004), succession can generate processes of change that strengthen the business formula and consolidate the sources of competitive advantage (Compagno and Gubitta 2004). The transition at the strategic apex can and should 
be seen as an opportunity to simplify and improve the company or to introduce the necessary changes to ensure adequate levels of competitiveness in the medium and long term.

By reinforcing the business culture, succession of members can provide the basis for long-term strategies that reduce knowledge transmission costs. However, if business leaders have gathered training and experience within the company or family circle, this may restrict the company's ability to respond to external challenges or alter the internal organization. Training and experience within the company must be balanced with the contacts network of an outgoing business leader who can be commercial, financial or knowledge-based and that represents an element of the company's intangible assets (Colli, Fernández, and Rose 2003).

It is ironic that the process is so conflicting since one of the main objectives of internal succession in family businesses is to reduce uncertainty by maintaining family control. Although it is not the only factor determining the survival or prosperity in family businesses, the tumultuous nature of the generational transition has been identified as one of the main reasons why family businesses are often short-lived (Gallo 1998).

Ultimately, it is desirable that generational change could be seen not as a threat or as a mere rotation at the apex or as an opportunity to revolutionize society, but as a physiological stage in the family business life cycle, essential for its development and integration of the strategic path that it intends to carry out.

\section{STEP model}

Within the empirical analysis, six companies (three Italian and three Peruvian) were selected for an investigation carried out by the STEP project. 
The STEP project was created in 2005 by seven academic institutions. By 2015 there already were 40 academic institutions from five regions in the world, with 175 researchers involved. STEP is aimed at educating business families, focusing on their ability to create social and economic value, and to perpetuate this entrepreneurial legacy for many generations. The objectives are focused to understand the transgenerational nature of business groups and families, to determine how they foster the creation of new entrepreneurial initiatives over time and to identify the best family practices aimed at generating, maintaining and transmitting the entrepreneurial spirit throughout generations.

To achieve the objectives, STEP proposes a transgenerational entrepreneurship model that especially includes these key components:

- Particular emphasis on the family as a unit of analysis, thus broadening the scope of analysis beyond the individual and organizational level.

- The business mindset from the family.

- The influence of the family on founds and the use of resources.

- Contextual factors such as industry, community culture, the stage of family life and the family participation.

- Performance and value creation measured in terms of business, financial and social performance as antecedents of the transgenerational potential.

STEP investigation used by this study was presented in February 2015. The survey was completed by 1043 participants, out of a total of 4162 eligible, with a response rate of $25.06 \%$. The study was carried out by research teams of the countries where the STEP project is located, which had direct contact with the participating family companies.

STEP PROJECT focuses on families motivated to change that have at least a second generation, with an ownership of at least three family members and another one in management. 
Figure 1. Revised case STEP form

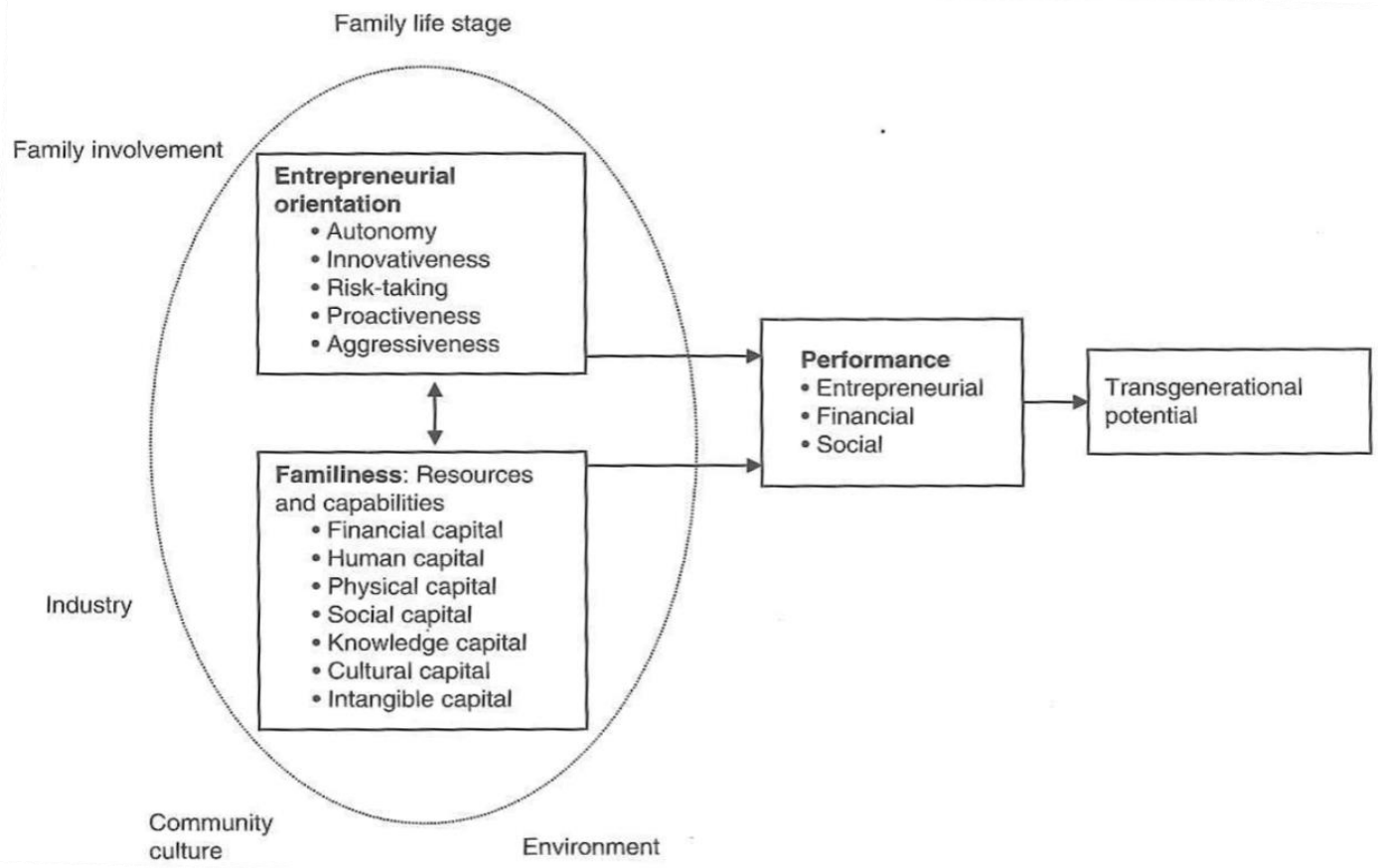

Source: STEP, 2013-2014

\section{Businesses' profiles}

For the present study, business families were selected according to the relevant information, regarding the following criteria:

- one family runs a single company;

- in the company they are simultaneously active at least two generations;

- there has been a generational change desired by the family and not required by force majeure;

- profiles of two different generations of the same family are present in the research.

What also characterizes the family companies that participate in this survey is their long-term vision, their flexibility and independence to make timely decisions, their entrepreneurial spirit, 
their commitment to society and workforce, their values and culture, the close relationship with their staff and clients, as well as being a guide for the family.

The data used for the comparison are the result of a selection of more than 100 questions addressed to family companies chosen by the STEP project. By comparing the responses of the six companies selected using the STEP model, I was able to the trace of each family member's profile and the calculation of their transgenerational potential was possible.

The limited number of cases, obviously, does not allow for statistically significant results. However, it is considered that the analysis of these cases can provide interesting reflections. Companies ${ }^{1}$ selected are synthetically described in Table 3.

Table 3. Companies description

\begin{tabular}{|c|c|c|c|c|c|}
\hline Company & & Sector & Characteristics & $\begin{array}{l}\text { Involved } \\
\text { generations }\end{array}$ & Interviewed \\
\hline $\begin{array}{l}\text { Company } \\
\text { Peru }\end{array}$ & 1 & Commerce & $\begin{array}{l}\text { Control: } 70 \% \text { family } \\
\text { Employees: } 123 \\
\text { Sales: } \$ 1 \mathrm{M}-\$ 5 \mathrm{M}\end{array}$ & $1^{\circ}, 2^{\circ}$ y $3^{\circ}$ & $\begin{array}{l}\text { Founder }\left(1^{\circ} \text { gen. }\right) \\
\text { Director }\left(2^{\circ} \text { gen. }\right)\end{array}$ \\
\hline $\begin{array}{l}\text { Company } \\
\text { Peru }\end{array}$ & 2 & Construction & $\begin{array}{l}\text { Control: } 100 \% \text { family } \\
\text { Employees: } 20 \\
\text { Sales: } \$ 500 \mathrm{~K}\end{array}$ & $1^{\circ}, 2^{\circ}$ y $3^{\circ}$ & $\begin{array}{l}\text { Director }\left(2^{\circ} \text { gen. }\right) \\
\text { Employee }\left(3^{\circ} \text { gen. }\right)\end{array}$ \\
\hline $\begin{array}{l}\text { Company } \\
\text { Peru }\end{array}$ & 3 & Construction & $\begin{array}{l}\text { Control: } 100 \% \text { family } \\
\text { Employees: } 40 \\
\text { Sales: } \$ 5 \mathrm{M}-\$ 10 \mathrm{M}\end{array}$ & $1^{\circ}$ y $2^{\circ}$ & $\begin{array}{l}\text { Founder }\left(1^{\circ} \text { gen. }\right) \\
\text { Director }\left(2^{\circ} \text { gen. }\right)\end{array}$ \\
\hline $\begin{array}{l}\text { Company } \\
\text { Italy }\end{array}$ & 1 & Commerce & $\begin{array}{l}\text { Control: } 70 \% \text { family } \\
\text { Employees: } 20 \\
\text { Sales: } \$ 1 \mathrm{M}-\$ 5 \mathrm{M}\end{array}$ & $1^{\circ} \mathrm{y} 2^{\circ}$ & $\begin{array}{l}\text { Founder }\left(1^{\circ} \text { gen. }\right) \\
\text { Director }\left(2^{\circ} \text { gen. }\right)\end{array}$ \\
\hline $\begin{array}{l}\text { Company } \\
\text { Italy }\end{array}$ & 2 & Textile & $\begin{array}{l}\text { Control: } 100 \% \text { family } \\
\text { Employees: } 130 \\
\text { Sales: } \$ 10 \mathrm{M}-\$ 15 \mathrm{M}\end{array}$ & $3^{\circ} \mathrm{y}^{\circ}$ & $\begin{array}{l}\text { Director }\left(3^{\circ} \text { gen. }\right) \\
\left.\text { Director ( } 4^{\circ} \text { gen. }\right)\end{array}$ \\
\hline $\begin{array}{l}\text { Company } \\
\text { Italy }\end{array}$ & 3 & Construction & $\begin{array}{l}\text { Control: } 100 \% \text { family } \\
\text { Employees: } 15 \\
\text { Sales: } \$ 10 \mathrm{M}-\$ 15 \mathrm{M}\end{array}$ & $1^{\circ}, 2^{\circ}$ y $3^{\circ}$ & $\begin{array}{l}\text { Founder }\left(1^{\circ} \text { gen }\right) \\
\text { Director }\left(3^{\circ} \text { gen. }\right)\end{array}$ \\
\hline
\end{tabular}

Source: STEP 2013-2014 survey.

\footnotetext{
${ }^{1}$ For a privacy issue, all the companies in the STEP project are not identified. Therefore, in this study we have used fancy names to differentiate them.
} 


\section{Entrepreneurial orientation}

Entrepreneurial orientation (EO) represents, qualifies and characterizes the health status of business innovation ecosystems.

Entrepreneurship encompasses all the people within the company. The entrepreneurial orientation refers to the attitude of the managers and executives of the company, as members of an organization with rules and procedures, to accommodate and encourage the emergence of business ideas. Numerous experimental studies state that a high business orientation corresponds to better results in terms of sales, market share and size of companies (Rauch et al. 2009).

Initially, EO had only three constructs - innovation, risk and proactivity - that should covariate positively for EO to manifest it. Later, in the mid-1990s, Lumpkin and Dess (1996) extended the domain of the EO construct, including two additional dimensions: competitive aggressiveness and autonomy.

\section{Autonomy}

Autonomy can be understood as an independent action by an individual or team to launch an idea or a vision and carry it through to completion (Lumpkin and Dess 1996). In other words, it is about the ability and willingness to decide freely for oneself to pursue market opportunities. Within the conceptual framework of the EO, autonomy has a very important role in boosting the strengths of a company, identifying opportunities that are outside the organization's capabilities and reinforcing to carry out new projects that improve business practices (Kanter 1983). Thus, autonomy reinforces innovation, stimulates start-up of business projects and improves competitiveness and efficiency within organizations (Burgelman 1984).

In our case, for Italian and Peruvian business families, autonomy is not a sensitive issue that 
matters much. In particular, Peruvian companies do not support individual efforts or autonomous working groups, nor do they encourage individuals to become autonomous. Mainly, in Company 2 Peru, it is observed that the best results do not happen when the person and/or the group decide for themselves, but when there is a comparison between the collaborators. The relevant issue is that the third generation thinks that they should not work with much autonomy and that it is not necessary to give employees so much autonomy. The lack of autonomy is also noted by comparing the number of informal meetings that the family organizes, which is a number higher than the average of the rest of the companies in the study.

\section{Innovation}

The key factors of innovation are vision of the future, shared vision and commitment to learning, so that it does not limit or punish a company's employees for making mistakes (Wang 2008). Innovations, which reflect the result of a dimension that has gained importance in recent years due to the rapid movements of markets and the changing needs of customers, can be classified, according to their focus, as external and internal.

With the available data for the companies examined, we can focus mainly on external innovation. It can be seen that Peruvian companies are most often the first in their own market to introduce new services/technologies (especially Company 1 Peru and Company 1 Italy). On the other hand, Italian companies have introduced new lines and more changes in products/services in the last five years. This can be justified by the greater competition that the market imposes on the companies to diversify and to attract more clients with a constant innovation.

Comparing the responses of the different generations, we see how the last generation has a more positive and innovative vision than the previous generation. This can be justified by a more 
open mindedness of the new generation, and the technological progress that is increasing over the years.

\section{Assumption of risks}

Risk assumption consists of daring actions, such as venturing into the unknown, massive contracting and compromising resources in launching new products with a high degree of uncertainty (Rauch et al. 2009). In other words, it typifies the degree of willingness of management to compromise enterprise resources when the decision has a considerable probability of failure (Lumpkin and Dess 1996).

In the case of family businesses, the idea that these types of companies assume the risk in a different way has been widely accepted. This is because management and ownership are not separated as well as the family nature of ownership and management (Carney 2005). Naldi et al. (2007) state that family businesses are more risk-averse because most of the family's wealth is often invested in the firm, fully supporting the hypothetical financial losses of failed investments.

These theses are not fully validated by the companies examined; in fact, the six companies are trying to encourage mostly low-risk projects (Italians rather than Peruvian ones), with prudent behavior to minimize the likelihood of costly decisions. Peruvian companies, moreover, explore the environment with gradual actions more than the Italian ones. Therefore, there is evidence that these organizations are not as risk-averse as literature claims when it comes to family businesses. This is justified by the claim that in such a competitive market, a wrong decision could endanger the life of the company.

\section{Proactivity}

Proactivity refers to processes that aim to anticipate and operate in future needs, by seeking 
new opportunities that may or may not be related to the usual line of action, the introduction of new products and brands - before the competition — and the elimination of operations, which are strategically in the stages of maturity or decline of the cycle of life.

In the case of family firms, Zellweger and Sieger (2010) said that the pattern of proactivity is dynamic, with periods of low levels of proactivity and other phases of well-studied movements. The level varies depending on the generation owned by family businesses, and this level of proactivity can be quite widespread.

In addition, Short et al. (2009) indicates that large family firms exhibit lower levels of proactivity compared to non-family ones. This conclusion is in line with the fact that defensive strategy is the most common strategic approach employed by family firms.

The companies studied play a moderately important role in identifying and selecting opportunities, limiting themselves to encouraging people and/or teams to make decisions regarding business opportunities, without constantly consulting their supervisor(s) On the contrary, Company 1 Peru tries to play an important, active and, above all, faster role than its competitors in the individualization and choice of opportunities.

\section{Competitive aggressiveness}

Competitive aggressiveness refers to the tendency of a company to challenge its competitors in a direct and intense way in order to outdo competitors in its sector (Lumpkin and Dess 1996). Competitive aggressiveness can take different forms. All of them are based on acquiring larger market shares and customers attacking the weaknesses of competitors in order to reduce their ability to compete, and also to anticipate and respond to what an aggressive rival company hopes to do in the future ( Hughes and Morgan 2007).

In the case of family businesses, their views and ways of acting tend to be different from non- 
family ones. Within this dimension there are at least two different behaviors. One is the adoption of an aggressive attitude in order to undo the position of the competitors, while the other behavior is the attitude known as "live and let live" (Covin and Covin 1990).

This latter form is the one that best represents Peruvian companies, more oriented towards an approach that tries to avoid any kind of confrontation with competitors. They are not particularly aggressive and competitive. They simply observe the actions of the competitors and take sporadic actions to obtain business from them.

As Martin and Lumpkin (2003) argue, participation in company control by different generations affects the intensity level of this dimension. In fact, as later generations become involved in the family business, competitive aggressiveness tends to be less. This is confirmed by comparing the responses of the two generations of companies.

\section{Familiness and resources}

Analyzing family businesses, we can observe the existence of a set of resources that differentiate each of these organizations from other companies. This set of resources can be the product of the constant interaction between the company and the family. Habberson and Williams (1999) characterize this set of resources, which he calls familiness and is defined as "that set of resources that are distinctive of a company as a result of its implication in a family". If we analyze the resources that will integrate the family, they must necessarily be those that can characterize the organizations. Thus, far from referring to any type of tangible asset, which may be available to any organization, they should be limited to certain intangible assets and capabilities and, in particular, to knowledge-based resources. If we consider the set of resources that will compose the familiness, it is easy to verify that these are valuable resources for the company; heterogeneous, since they are characteristic of each organization; imperfectly mobile, 
especially because of belonging to a family of the company; and difficult to reproduce by other companies, especially because of their causal ambiguity.

STEP considers in its model of familiness seven resources that, combined, make each company a unique and distinct entity.

\section{Financial capital}

In companies ruled by a small number of people, the owners control the management of capital and the distribution of profits in a particular way. This control can mean an advantage (generates expectations of long-term gains) or a disadvantage (conflicts between shareholders who demand capital and managers who prefer to reinvest). Financial capital should take into account aspects such as debts, money flow, strategic alliances and other ways of managing the capital. Four of the six business families considered in this research have total control of the financial capital of the company; the other two, one Italian and one Peruvian, have $70 \%$. All with sufficient freedom to manage capital, having control over all financial movements.

From the STEP survey data, it can be seen that there is no significant difference between firms in terms of availability and control of financial capital. It can be seen that for Peruvian companies it is more important to reinvest most of the profits in the company, used mainly to renew the productive processes.

\section{Family culture in the company}

The culture of an organization is formed by the beliefs, ways of acting, rules, etc., that create the internal environment of the company. The culture components discussed include values, vision, behavior, and traditions of the family and organization, especially those related to the impact the family has on the company.

The positive reputation of the business family is fundamental. This is a requirement that is not 
only found in the six companies analyzed, but is present in most companies in Peru. Good reputation is considered a discriminator to highlight the competition.

In Italian companies, it was found that the impact of the family on the identity and harmony of the company is stronger and evident.

\section{Intangible capital}

The ability of a company to realize its strategy depends, in the definition, on the non-material factors — intangibles — of the firm's capital. Intangible capital does not directly participate in the generation of value, but generates it when it joins other intangible factors. Its value depends on the goals of the company and its ability to achieve them; this makes objective measurement difficult.

Intangible capital includes several aspects: the network of contacts with people and organizations that are not part of the company (suppliers, customers, stakeholders) and what is defined as human capital: a set of knowledge, skills, abilities, emotions that each collaborator puts at the disposal of the company, being the mentioned the main ones. The education, experience, skills and learning capabilities of family members and non-family members working in or with the company reflect the knowledge and skills retained by the family members.

From the interviews with the selected family companies, it was demonstrated that they consider essential that employees have experience and are sufficiently aware of the productive process in which the company operates. Only Company 1 Peru does not think it necessary to choose informed employees (this, because the company organizes training courses). 


\section{Performance}

The performance of family businesses, as well as the ability to create value, has been the subject of intense international debate for several years (Yu et al. 2012; O'Boyle, Pollack, and Rutherford 2012; Gedajlovic et al, 2012; Mazzi 2011; Zellweger, Eddleston, and Kellermanns 2010). The wide spread of the phenomenon, the particular nature of family businesses, the complexity of the resources derived from the interaction between family and company systems and the contrasting effects that are being realized on the performance of the business have encouraged the proliferation of a debate on the relationship between familiarity and performance. Despite the profusion of studies, the literature has not achieved consistent results (O'Boyle et al. 2012; Chrisman, Chua, and Steier 2005). Some research has shown the existence of a positive relationship between family participation and performance (Van Essen, Van Oosterhout, and Carney 2011; Sraer and Thesmar 2007; Martínez, Stohr, and Quiroga 2007); however, others have shown that the family effect has a negative impact on the firm's performance (Westhead and Howorth 2006; Filatotchev, Lien, and Piesse 2005). Others reveal that there is no significant relation, evidencing that the family character may not be sufficient by itself to explain the performance of the company and that, therefore, the focus of the research must move in the search for variables and/or moderators of relationship mediation (Villalonga and Amit 2006; Daily and Dollinger 1992).

Like the literature, the case studies that have been analyzed reflect uncertainty about the performance of family-run companies. In reference to the performance of the three years prior to the interview, there is a strong difference between the six companies when comparing them with the competition. In Company 2 Italy, for example, the growth of its sales has been 
considerably smaller than the one of its competition. Company 1 Italy, on the other hand, it has had a much better sales increase than its competitors in the last three years.

In general, Peruvian companies have had a greater financial growth over their competitors than Italian companies, and are distinguished because of a greater attention on the subject of social performance, trying to reduce the environmental impact of production and educating their employees on the matter.

\section{Conclusions}

In order to study the generational change, which represents the most significant moment of change for family companies, this work analyzes it in several aspects. The objective that has guided our research has been to enrich the debate on the issue of generational change in family businesses, comparing Italian and Peruvian companies, in search of identifying any similarity or difference in the management and approach to succession.

In general, the six companies examined do not show great diversity in the management of generational change. For example, in macro-themes such as family relations that influence the life of the company, we can point out that there is a particularity (the low harmony and low development of the new generation in Company 2 Italy), but they are identified in a single company and that does not characterize the others.

It is worth noting that Italian companies focus more on management practices, trying to constantly improve performance, with the aim of increasing sales, neglecting the intangible aspects such as the development of human capital and family life, aspects in which Peruvian companies focus more.

For a family business to have transgenerational potential, it is essential to maintain good 
relations among family members. This relationship allows the sustainability of the company. It is observed that in the six companies studied, the first generation strives to transmit the basic values of the family to their children. These values are projected to companies. Family members respect family business partners and care about communicating with them constantly.

All the interviewees of the last generation, who theoretically would have to manage the companies, are willing to maintain the entrepreneurial spirit. They are aware of the importance of maintaining control of the organization among the family.

With the results obtained, we can once again validate one of the most supported theses in the literature: the succession and generational change represents one of the most important moments in the life of a family business because it is and it can be a crossroads between the continuation of business activities and the closure of the company, so that companies live this with fear and concern.

Figure 2. Mean values of the responses for the model variables

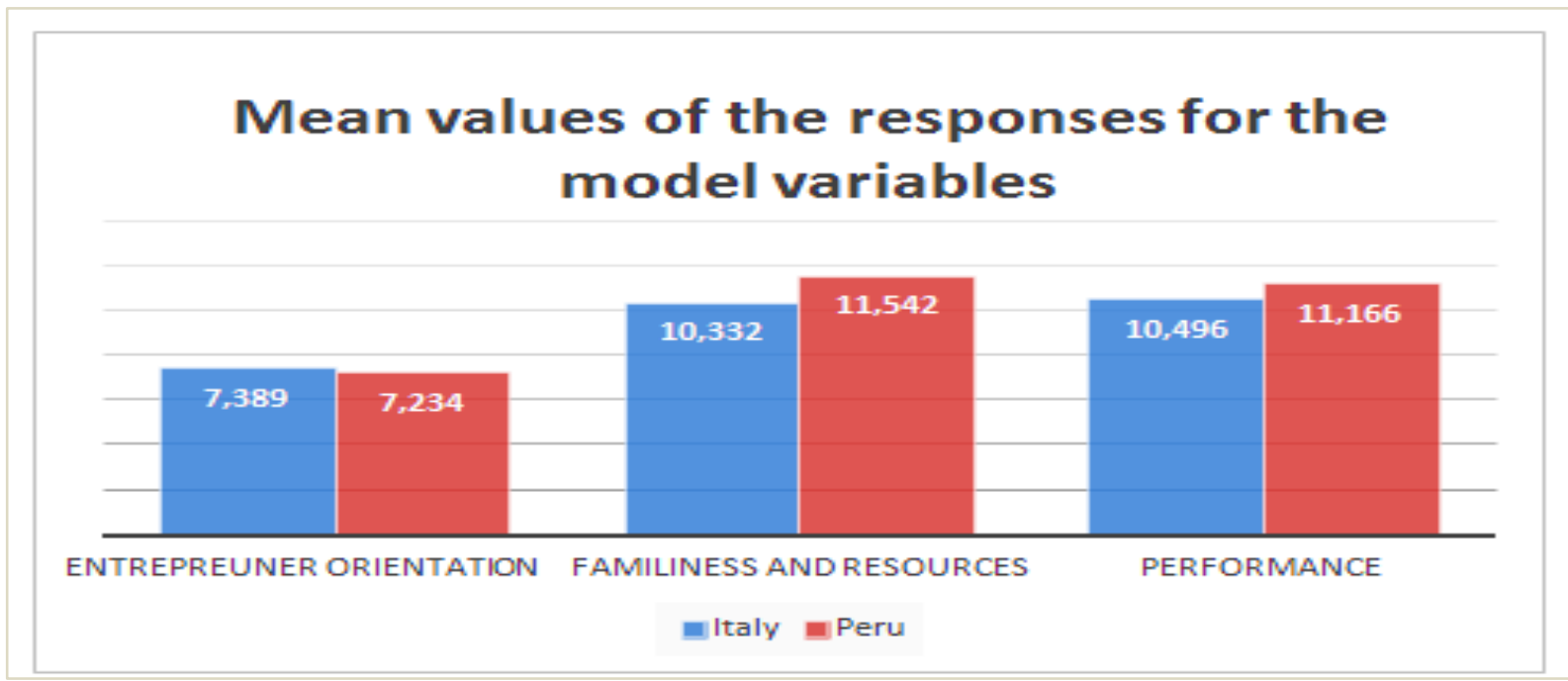

Source: STEP Survey 2014 Own elaboration

Only by planning and considering it, not as a threat or as a mere rotation, but as a physiological stage in the family business life cycle, succession can be a key opportunity to spread the 
innovative spirit in the company and to initiate the process of change carried out according to a logic oriented to the future, where continuity and renewal, tradition and innovation are combined.

Finally, the available data have not been sufficient to obtain a clear and definite idea of each company, but it can be said that the six companies investigated have a good transgenerational potential and are ready for a successful generational change.

\section{References}

ARMAL - Agenzia Regionale Marche Lavoro. 2003. Il passaggio generazionale nelle piccole e medie imprese nelle Marche. Progetto di ricerca. Università Politecnica della Marche.

Barach Jeffrey A., and Joseph B. Ganitsky. 1995. "Successful succession in family business." Family Business Review 8:131-155.

Beckhard, Richard, and W. Gibb Dyer Jr. 1983. "Managing continuity in the family-owned business." Organizational Dynamics 12 (1): 5-12.

Berle, Adolf A., and Gardiner C. Means. 1932. The modern corporation and private property. New York: World Inc.

Boldizzoni, Daniele, Antonella Cifalinò, and Luigi Serio. 2000. "L’impresa familiare: modelli di analisi ed evidenze empiriche. Una ricerca sull'imprenditorialità marchigiana." Piccola Impresa/Small Business 3.

Burgelman, Robert A. 1984. "Designs for corporate entrepreneurship in established firms." California Management Review 26 (3): 154-166.

Carney, Michael. 2005. "Corporate governance and competitive advantage in family-controlled firms." Entrepreneurship, Theory and Practice 29 (3): 249-265.

Centeno-Caffarena, Leonardo. 2006. "The role of informal institutional factors in the family business." Paper presented at the Pre-communication to Congress of Economics and Business Administration, Universitat Autònoma de Barcelona.

Chrisman, James J., Jess H. Chua, and Lloyd P. Steier. 2005. "Sources and consequences of distinctive familiness: an introduction." Entrepreneurship, Theory and Practice 29:237-247.

Chua, Jess H., and James J. Chrisman. 1999. "Defining the family business by behavior." Entrepreneurship Theory and Practice 23 (4): 19-39. 
Chua, Jess H., and James J. Chrisman. 2003. “A unified perspective of family performance: an extension and integration." Journal of Business Venturing 18 (4): 467-472.

Ciambotti, Massimo. 1991. "I processi di transizione imprenditoriale nelle imprese familiari di minore dimensione." Piccola Impresa/Small Business 1.

Colli, Andrea, Paloma Fernández Pérez, and Mary Rose. 2003. "National determinants of family firm development? Family firms in Britain, Spain and Italy in the Nineteenth and Twentieth Century's." Enterprise and Society 4 (1): 28-64.

Compagno, Cristiana. 1999. "Assetti istituzionali e transizione generazionale nelle PMI." CuoaRivista 2.

Compagno, Cristiana, and Paolo Gubitta. 2004. "Le PMI del Nordest tra continuità e sviluppo: una nuova classe imprenditoriale?" Nordesteuropa it 1.

Corbetta, Guido. 1995. Le imprese familiari. Caratteri originali, varietà e condizioni di sviluppo. Milano: Egea.

Covin, Jeffrey G., and Teresa J. Covin. 1990. "Competitive aggressiveness, environmental context, and small mills" Administrative Science Quarterly 52 (1): 106-137.

Cucculelli, Marco. 2004. "Imprenditorialità e progetti di innovazione nel passaggio generazionale dell'impresa. Il caso delle Marche." Economia Marche 3.

Daily, Catherine M., and Marc J. Dollinger. 1992. "An empirical examination of ownership structure in family and professionally managed firms." Family Business Review 5 (2): 117-136.

Del Bene, Luca. 2005. Aziende familiari tra imprenditorialità e managerialità. Torino: Giappichelli.

Dyck, Bruno, Michael Mauws, Frederick A. Starke, and Gary A. Mischke. 2002. "Passing the baton: The importance of sequence, timing, technique and communication in executive succession." Journal of Business Venturing 17 (2).

EY - Ernest \& Young. 2014. "Family Business Year Book.” Accessed June 03.

http://familybusiness.ey.com/insights/family-business-yearbook-2014.aspx\#6.

Filatotchev, Igor, Yung-Chih Lien, and Jenifer Piesse. 2005. "Corporate governance and performance in publicly listed, family controlled firms: evidence from Taiwan." Asia Pacific Journal of Management 22 (3): 257-283.

Fondo Formazione Piccole Medie Imprese. 2017. "La continuazione generazionale nelle PMI: analisi dello stato dell'arte, individuazione delle best practice e degli incentivi a livello italiano ed europeo." Accessed June 29. http://www.fondopmi.com/wp-content/uploads/2009/12/Lacontinuazione-generazionale.pdf. 
Gallo, Miguel Ángel. 1995. "Empresa familiar: fortalezas y trampa, in Sindicato empresarial.” Alaves (eds.), Jornadas sobre la Empresa Familiar, Vitoria: 9-26.

Gallo, Miguel Ángel. 1998. La sucesión en la empresa familiar. Colección de Estudios e Informes Número 12. La Caixa: Barcelona.

Gedajlovic, Eric, Michael Carney, and James J. Chrisman. 2012. "The adolescence of family firm research." Journal of Management 38 (4): 1010-1037.

Habberson, Timothy G., and Mary L. Williams. 1999. "A resource-based framework for assessing the strategic advantages of family firm." Family Business Review 12 (1): 1-25.

Handler, Wendy C. 1989. "Methodological issues and considerations in studying family businesses." Family Business Review 2.

Harris, Ron. 2000. Industrializing English law: Entrepreneurship and business organization. Cambridge: Cambridge University Pres.

Heck, Ramona K.Z., and Kathryn Stafford. 2001. "The vital institution of family business: economic benefits hidden in plain sight." In Destroying myths and creating value in family business, edited by G. K. McCann, and N. Upton, 9-17. Deland: Stetson University Press.

Hughes, Mathew, and Robert E. Morgan. 2007. "Deconstructing the relationship between entrepreneurial orientation and business performance at the embryonic stage of firm growth." Industrial Marketing Management 36:651-661.

Ip, Barry, and Gabriel Jacobs. 2006. "Business succession planning: a review of the evidence.” Journal of Small Business and Enterprise Development 13 (3): 326-350.

Jaramillo, Fidel. 2014. "Presentación del documento de sistematización del Programa de Desarrollo de Sistemas de Gobierno y Gestión de Empresas." Conferencia del Programa de Desarrollo de Sistemas de Gobierno y Gestión de Empresas de Propiedad Familiar, organizada por la Cámara de Comercio de Lima y el Banco Interamericano de Desarrollo, Lima, Peru, November 26.

Kanter, Rosabeth Moss. 1983. The change masters: Innovation and entrepreneurship in the American corporation. New York: Simon and Schuster.

Kets de Vries, Manfred F.R. 1993. "The dynamics of family controlled firms: the good and the bad news." Organizational Dynamics 21 (3): 59-71.

Lassini, Ugo. 2005. "La cessione dell'impresa familiare: motivazioni e conseguenze." Economia \& Management 3:55-70.

Le Breton-Miller, Isabelle, Danny Miller, and Lloyd P. Steier. 2004. "Toward an integrative model of effective FOB succession.” Entrepreneurship Theory and Practice 28 (4): 305-328.

Lumpkin, G. Tom, and Gregory G. Dess. 1996. "Clarifying the entrepreneurial orientation construct and linking it to performance." Academy of Management Review 21 (1): 135-172. 
Martin, Wendy L., and G. Tom Lumpkin. 2003. "From entrepreneurial orientation to family orientation: generational differences in the management of family businesses." Paper presented at the Babson College Entrepreneurship Research Conference, Babson College, Wellesley, MA, USA, October. Martínez, Jon I., Bernhard S. Stöhr, and Bernardo F. Quiroga. 2007. "Family ownership and firm performance: evidence from public companies in Chile." Family Business Review 20 (2): 83-94.

Mazzi, Chiara. 2011. "Family business and financial performance: current state of knowledge and future research challenges.” Journal of Family Business Strategy 2 (3): 166-181.

McGivern, Chris. 1978. "The dynamics of management succession.” Management Decision 16 (1): 32.

Naldi, Lucia, Mattias Nordqvist, Karin Sjöberg, and Johan Wiklund. 2007. "Entrepreneurial orientation, risk taking, and performance in family firms." Family Business Review 20 (1): 33-47.

O'Boyle, Ernest H. Jr., Jeffrey M. Pollack, and Matthew W. Rutherford. 2012. "Exploring the relation between family involvement and firms financial performance: a meta-analysis of main and moderator effect." Journal of Business Venturing 27 (1): 1-18.

PwC. 2014. "Bridging the gap. Passare l'impresa familiare alla nuova generazione." Accessed June 29. http://www.pwc.com/it/publications/assets/docs/bridgingap.pdf

Rauch, Andreas, Johan Wiklund, Tom Lumpkin, and Michael Frese. 2009. "Entrepreneurial orientation and business performance: an assessment of past research and suggestions for the future." Entrepreneurship Theory and Practice 33 (3): 761.

Shanker, Melissa Carey, and Joseph H. Astrachan. 2004. "Myths and realities: family businesses' contribution to the US economy-A framework for assessing family business statistics." Family Business Review 9 (1): 107-123.

Short, Jeremy C., J. Christian Broberg, Claudia C. Cogliser, and Keith H. Brigham. 2009. "Construct validation using computer-aided text analysis (CATA): an illustration using entrepreneurial orientation." Organizational Research Methods 12:1-28.

Smith, Max. 2008. "Differences between family and non-family SMEs: A comparative study of Australia and Belgium.” Journal of Management \& Organization 14 (1): 40-58.

Sraer, David, and David Thesmar. 2007. "Performance and behavior of family firms: evidence from the French stock market.” The Journal of the European Economic Association 5 (4): 709-751.

STEP - Successful Transgenerational Entrepreneurship Practices. 2013-2014. "Quantitative Survey." Università Bocconi STEP research team and Universidad de Piura STEP research team. Tagiuri, Renato, and John A. Davis. 1992. "On the goals of successful family companies." Family Business Review 5 (1): 43-62. 
Van Essen, Marc, J., Hans van Oosterhout, and Michael Carney. 2011. "Corporate boards and the performance of Asian firms: a meta-analysis." Asia Pacific Journal of Management 29 (4): 873905.

Villalonga, Belén, and Raphael Amit. 2006. "How do family ownership, control and management affect firm value?" Journal of Financial Economics 80:385-417.

Wang, Catherine L. 2008. "Entrepreneurial orientation, learning orientation, and firm performance." Entrepreneurship Theory and Practice 32 (4): 635-657.

Ward, John L. 1987. Keeping the family business healthy: how to plan for continuing growth, profitability and family leadership. San Francisco: Jossey-Bass.

Ward, John L. 1991. Creating effective boards for private enterprises. San Francisco: Jossey-Bass Publishers.

Westhead, Paul, and Carole Howorth. 2006. "Ownership and management issues associated with family firm performance and company objectives.” Family Business Review 19 (4): 301-314.

Wortman, Max S. 1995. "Critical issues in family business: An international perspective of practice and research." In Proceedings of the ICSB 40th world conference, 53-76. Sydney, Australia, Institute of Industrial Economics.

Yu, Andy G., Tom Lumpkin, Ritch L. Sorenson, and Keith H. Brigham. 2012. "The landscape of family business outcomes." Family Business Review 25 (1): 33-57.

Zellweger, Thomas, and Philipp Sieger. 2010. "Entrepreneurial orientation in long-lived family firms." Small Business Economics 38 (1): 67-84. Accessed June 29, 2017. doi:10.1007/s11187-010-92676.

Zellweger, Thomas M., Kimberly A. Eddleston, and Franz W. Kellermanns. 2010. "Exploring the concept of familiness: introducing family firm identity." Journal of Family Business Strategy $1: 54-63$.

This is an Open Access article distributed under the terms of the Creative Commons Attribution-Non-Commercial-No Derivatives License (http://creativecommons.org/licenses/by-nc-nd/4.0/), which permits non-comercial re-use and distribution, provided the original work is properly cited, and is not altered or transformed in any way. 